\title{
Manajemen Bisnis
}

THE EFFECT OF FOOD QUALITY AND SERVICE QUALITY TOWARDS

CUSTOMER SATISFACTION AND REPURCHASE INTENTION

(CASE STOY OF HOT PLATE RESTAURANTS)

THE QUALITY OF IT PROJECT MANAGEMENT: THE BUSINESS PROCESS
AND THE GO PROJECT LEAN APPLICATION

Dewi Nusraningrum, Jaswati Jaswati, Hakiman Thamrin

ANALYSIS OF BEHAVIOR USING E-MONEY WITH A TAM APPROACH

(TECHNOLOGY ACCEPTANCE MODEL)

Indah Retno Wulandari, Sumad

THE EFFECT OF SERVICE QUALITY ON SATISFACTION AND LOYALTY VISITORS

AT SENGKALING RECREATIONAL PARK

Ardik Praharjo

PERFORMANCE OF MERGER AND ACQUISITION, DIRECTOR EXPERIENCE, AND MODERATION EFFECTS OF BOARD CHARACTERISTICS, BIDDER CHARACTERISTICS, AND TYPE OF MERGER AND ACQUISITION

Shindy Dwita Nuansari

THE EFFECT OF MANAGERIAL OVERCONFIDENCE ON CORPORATE INVESTMENT

Mochamad Ali Fudin Al Islami, Muhammad Madyan

ANALYSIS OF INVESTOR BEHAVIOR IN THE ISLAMIC CAPITAL MARKET WITH AN APPROACH TRA (THEORY OF REASONED ACTION)

Istu Putri Swasti

THE EFFECT OF FINANCIAL CONSTRAINT MODERATION IN CASH FLOW SENSITIVITY

Abu Hasan Ahmad, Maria Adventia Mentari Mayang Cardicna

LEARNING ORGANIZATION LEADERSHIP INNOVATION (LOLI) AND EMPLOYEE PERFORMANCE IN CREATIVE INDUSTRIES

Titiek Ambarwati, Fika Fitriasari, Ratya Shafira Arifiani

HOW DOES A UNIVERSITY OF CHOICE COME TO STUDENTS' MIND? FROM THE ASPECT OF THE E-SERVICESCAPE OF UNIVERSITY'S WEBSITE 


\author{
SUPERVISOR \\ Marsudi \\ EDITOR IN CHIEF \\ Widayat \\ MANAGING EDITOR \\ Novita Ratna Satiti \\ Sandra Irawati \\ EDITORIAL BOARD \\ Bambang Widagdo \\ Rahmad Wijaya \\ Fien Zulfikarijah \\ Eko Handayanto \\ Warsono \\ Aniek Rumijati \\ Uci Yulianti
}

\title{
TECHNICAL AND ADMINISTRATION SUPPORT
}

Kardina Yudha Parwati

Khusnul Rofida Novianti

Viajeng Purnama Putri

\begin{abstract}
EDITOR'S ADRESS
Manajemen Bisnis

Faculty of Economic and Business Muhammadiyah Malang University

JL. Raya Tlogomas No. 246 Malang Phone No. (0341) 464318 psw 214

E-mail: jurnal_mb@umm.ac.id
\end{abstract}

Manajemen Bisnis (JMB) is published by the Department of Management, Faculty of Economic and Business, University of Muhammadiyah Malang in 2011. In December 2018, JMB has got online ISSN for articles that publish started from Volume 9 No. 1, April 2019.

JMB is a peer reviewed and open acces journal which published twice a year (April and October). This journal published articles in indonesian but in $2019 \mathrm{JMB}$ publish all articles fully in english. This journal only accepts articles from original research results. JMB welcome all articles related to management and business fields. Subjects suitable for publication include but are not limited to the following fields: finance management, operation management, human resource management, marketing management, strategic management, management information system, knowledge management, entrepreneurship, business management, business innovation, international business, and business ethics.

Manajemen Bisnis has been indexed in Google Schoolar. JMB keep attempt to be indexed in others journal directories. 
MANAJEMEN BISNIS

Volume 10, No. 1, April 2020

\section{TABLE OF CONTENTS}

THE EFFECT OF FOOD QUALITY AND SERVICE QUALITY TOWARDS CUSTOMER SATISFACTION AND REPURCHASE INTENTION (CASE STUDY OF HOT PLATE RESTAURANTS)

Desman Hidayat, Aryo Bismo, Amelia Ruwaida Basri

THE QUALITY OF IT PROJECT MANAGEMENT: THE BUSINESS PROCESS AND THE GO PROJECT LEAN APPLICATION

Dewi Nusraningrum, Jaswati Jaswati, Hakiman Thamrin

ANALYSIS OF BEHAVIOR USING E-MONEY WITH A TAM APPROACH (TECHNOLOGY ACCEPTANCE MODEL)

Indah Retno Wulandari, Sumadi

THE EFFECT OF SERVICE QUALITY ON SATISFACTION AND LOYALTY VISITORS AT SENGKALING RECREATIONAL PARK Ardik Praharjo

PERFORMANCE OF MERGER AND ACQUISITION, DIRECTOR EXPERIENCE, AND MODERATION EFFECTS OF BOARD CHARACTERISTICS, BIDDER CHARACTERISTICS, AND TYPE OF MERGER AND ACQUISITION

Shindy Dwita Nuansari

THE EFFECT OF MANAGERIAL OVERCONFIDENCE ON CORPORATE INVESTMENT

Mochamad Ali Fudin Al Islami, Muhammad Madyan. $49-57$

ANALYSIS OF INVESTOR BEHAVIOR IN THE ISLAMIC CAPITAL MARKET WITH AN APPROACH TRA (THEORY OF REASONED ACTION) 
THE EFFECT OF FINANCIAL CONSTRAINT MODERATION IN CASH FLOW SENSITIVITY TO EXTERNAL FINANCING OF MANUFACTURING COMPANIES

Abu Hasan Ahmad, Maria Adventia Mentari Mayang Cardicna $65-78$

LEARNING ORGANIZATION LEADERSHIP INNOVATION (LOLI) AND EMPLOYEE PERFORMANCE IN CREATIVE INDUSTRIES

Titiek Ambarwati, Fika Fitriasari, Ratya Shafira Arifiani $79-89$

HOW DOES A UNIVERSITY OF CHOICE COME TO STUDENTS' MIND? FROM THE ASPECT OF THE E-SERVICESCAPE OF UNIVERSITY'S WEBSITE

Kardina Yudha Parwati $90-99$ 